\title{
The role of perceived usefulness in moderating the relationship between the DeLone and McLean model and user satisfaction
}

\author{
Muhartini Salim $^{a^{*}}$, Lizar Alfansia ${ }^{a}$, Sularsih Anggarawatia ${ }^{a}$, Fachri Eka Saputra ${ }^{a}$ and Chairil \\ Afandy ${ }^{a}$
}

${ }^{a}$ Department of Management, Faculty of Economics and Business, University of Bengkulu, Indonesia

\begin{tabular}{l}
\hline C H R O N I C L E \\
\hline Article history: \\
Received November 8, 2020 \\
Received in revised format \\
January, 28, 2021 \\
Accepted March 282021 \\
Available online \\
May 4 2021 \\
\hline Keywords: \\
System quality \\
Information quality \\
Service quality \\
User satisfaction \\
Perceived usefulness
\end{tabular}

A B S T R A C T

\begin{abstract}
The aim of this paper is to examine one of the most crucial factors in the "Technology Acceptance Model" proposed by Davis (perceived usefulness) in moderating the "DeLone and McLean" success model in the context of educational portal in Higher Education. Questionnaires were distributed online to 200 respondents and deserved to be analyzed. The respondents were regular students at the University of Bengkulu. Data analysis used Smart-PLS version 3.2.9. The research findings indicated an influence of "system quality, information quality, and service quality partially on user satisfaction" of the educational portal information systems. The result shows that perceived usefulness can strengthen the relationship between system quality, information quality, and service quality to the satisfaction of customer. This research contributes to the development of perceived usefulness variable as a moderating variable affecting the quality of a system, quality of information, and quality of service partially on user satisfaction and finding strategies needed by the University of Bengkulu effective and efficient information system.
\end{abstract}

C 2021 by the authors; license Growing Science, Canada.

\section{Introduction}

The data system is currently developing rapidly, creating institutions' tendency to use it to attain acceptable performance. Information is easy to obtain because of the advancement of information and communication technology. Technological developments have contributed positively to the utilization of a data system. The consequences of data technology encourage organizations to use technology. Technically, a system can be characterized as "a group of interrelated components that collect or retrieve, process, store, and distribute information to support decision-making and control in a business" (Laudon \& Laudon, 2014). The model proposed during this study aims to research factors that influence the data system's success. The Delone \& Mclean (1992) model is well-known within the academic literature, very appropriate for organizing studies on an information system's success. Higher education must hold a good, equitable, and quality education for the community. Thus, the knowledge system makes a big impact on the implementation of the education sector. The successful use of data systems in tertiary institutions will provide useful tertiary stakeholders, like students, lecturers, tertiary institutions, and community organizers. User satisfaction is that the user's response and feedback after using the information system (Petter et al., 2008). A user, satisfied with the information system, will affect his performance. According to Amoli \& Farhoomand (1996), "organizational performance and individual performance are judged by satisfaction when using information systems." Students in higher education, as one of the information system users, need to increase their satisfaction. If they are satisfied, they have the motivation to improve their performance by completing quality courses. According to Dessler (2017), an indication of performance inorganizations refers to completing quality work. User satisfaction in an information system is different from consumer satisfaction in marketing theory. Consumer satisfaction will affect loyalty. According to Van Vuuren et al.(2011), if consumers are satisfied, it will affect loyalty.

\footnotetext{
* Corresponding author

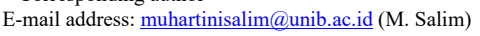

(C) 2021 by the authors; licensee Growing Science. doi: $10.5267 /$ j.uscm.2021.4.002
} 
Satisfaction contains a positive and significant impact on the loyalty of customers. Three factors are essential in the determined Information System (IS) qualities: "the quality of system, the quality of service, and the quality of information" (Delone \& Mclean, 2003). These three factors are considered necessary for influencing user satisfaction. This research used the updated successful level theory from DeLone and McLean data system model consisting of 6variables: "quality of system, quality of information, quality of service, user experience, user satisfaction, and net profit" (Delone \& Mclean, 2003). Technological Acceptance Model (TAM), developed by Davis, F.D, combined with behavioral theory. According to Davis (1989), TAM consists of 3 components: "perceived ease of use" (PEU), "perceived usefulness" (PU), and Attitude toward Using. However, this research only used the perceived usefulness variable as a moderating variable. There are many studies on a system that used the success model of DeLone \& McLean. Chiuet al. (2007); Seddon \& Min-Yen Kiew (2020); Michel \& Cocula (2017) stated that Information quality encompasses a positive and significant impact on the satisfaction of users. The quality of the system has a positive and essential influence on the satisfaction of users(Negash et al., 2003; Petter et al., 2008). The quality of service has a positive and significant effect on customer satisfaction (Yakubu \& Dasuki, 2018; Tajuddin, 2015;Jaafreh, 2017). We use perceived usefulness as a moderating variable to find if it strengthens or weakens the effect quality of a system, quality of information, and quality of service partially on user satisfaction. Previous studies have not looked at the role of perceived usefulness as a moderating variable in influencing the result to the best of our knowledge. Therefore, our work contributes to the literature by studying perceived usefulness. University of Bengkulu, Indonesia, since 2009, has used an information system, namely the University of Bengkulu Portal System. It consists of 8 portals, one of which is the academic portal of the University of Bengkulu. This academic portal covers all the processes starting from student admission until graduation, documented by a computer application. All the students must be served well to their satisfaction to increase student performance. The University of Bengkulu academic portal tries to provide good service, but students say that this portal has shortcomings and constraints. The interviews with several University of Bengkulu students indicated some drawbacks such as errors when opening the portal, the notice of class attendance saying the class is full. Still, it is not, so students have to go to the faculty building or LPTIK UNIB, the internet is often slow, so students need to use their internet quota, and internet access points are not the same. Based on these interview results, it was necessary to analyze the success of the University of Bengkulu academic portal. The research aimed to determine whether system quality, information quality, and service quality partially affect user satisfaction and the perceived usefulness variable moderating the influence of system quality, information quality, and service quality partially on user satisfaction. Besides, this research was necessary because its findings will contribute academically to the development of perceived usefulness variable theory as a moderating variable affecting the quality of system, the quality of information, and the quality of service partially on user satisfaction. This research's last objective was to seek out strategies needed by the University of Bengkulu to produce an effective and efficient data system (academic portal).

\section{Review of Relevant Literatures and Hypothesis Development}

\subsection{Information System}

The developments of information technology encourage institutions to use technology as processors and information providers. The current information system (IS) in universities has become necessary to support the educational process, such as an academic portal. According to O'Brien \& Marakas (2011), an information system is "combinations that are regulated by humans, hardware, software, communication networks, and data to collect, change, and disseminate information within an organization. In line with Delone \& Mclean (1992), the standard of information is produced by the knowledge system used. The D\&M model has also proven useful as a framework for regulating the measurement of information system success. This model has been widely employed by system researchers to grasp and measure data system success (Petter et al., 2008).

\subsection{Quality System}

System quality usually focuses on the characteristics of system performance. DeLone and Mclean (2003) stated that quality of system is "a characteristic of the system's preferred quality and information quality desired by-product characteristics". System quality is used to calculate the quality of the information system itself, both software and hardware. It is the system's performance, which alludes to how well the capabilities of the equipment, program, arrangements, and methods of the data framework can give data on client needs (DeLone \& Mclean, 1992). System quality is measured subjectively by the users, so what is used is perceived system quality. Indicators used were the replication from Gable et al. (2008) that consists of five measurement scales: ease of use, flexibility, reliability, speed of get to (response time), and framework security.

\subsection{Information Quality}

According to DeLone and Mclean (1992), "the quality of information is the output produced by the information system used. The performance dimension of the quality of information is a desirable function of the output of the information system. The quality of information is "the production quality in the type of information supplied by the device used". The knowledge is not data-related. Data is information that has been processed in a relevant way to the user and helpful in making current or future decisions. Research of DeLone and Mclean (1992) states that information quality is "a system that can affect satisfaction of user". Indicators of measuring the quality of information used are the replication of Research of 
Gable et al. (2008) consisting of 5 (five) measurement scales, namely: availability of information completeness, ease of understanding, presentation of information, the relevance of needs, and information accuracy.

\subsection{Service Quality}

According to Kotler and Keller (2015), "Service quality is the totality of characteristics of goods and services that demonstrate the ability to satisfy the needs of customers both explicitly and implicitly". Researchers can combine a model of the service improvement quality with the DeLone and McLean success model. Quality of service is "an instrument of the marketing literature, and it has become prominent in the literature of the success of an information system" (Petter et al. 2008). The fundamental of service quality in the information systems literature comes from researchers in marketing. Parasurahman et al. (1988) highlighted five dimensions the quality of service: reliability, responsiveness, assurance, empathy, and tangible. Reliability is "the ability to perform the promised service is reliable and accurate". Responsive is "willingness to help customers and provide fast service". Assurance is "knowledge and courtesy of employees and their abilities to inspire confidence and self-confidence". Empathy is "caring, individual attention provided by the company to its customers". Tangible is "physical facilities, equipment, and personal appearance" (Parasurahman et al., 1988). However, this research's service quality indicators were replicated from April and Pather (2008), namely responsiveness, assurance, and empathy.

\subsection{User Satisfaction}

Petter et al. (2013) define satisfaction of users as "the level of user satisfaction with IS". DeLone and McLean (1992) define satisfaction of the user as "the recipient's response to using the information system's output". In information systems studies, researchers have adopted user satisfaction measures based on repetition rates, which function as overall satisfaction with information system applications (Delone \& Mclean, 1992; Petter et al., 2013). Many researchers tend to use "user satisfaction" as a measure of results (Bokhari, 2005). In using the system, user satisfaction can improve productivity, performance, and effectiveness (DeLone \& Mclean, 2003). The level of user satisfaction when using an information system is the success dimension of user satisfaction. However, the indicators used in this research are replicated by Almutairi and Subramanian (2005), which consists of efficiency, effectiveness, and overall satisfaction.

\subsection{Perceived Usefulness (PU)}

PU is the perception that people believe that certain subjects' use will improve their work performance (Davis, 1989). It is also among the variables TAM of Davis's. TAM is "the research model most often used to examine the adoption of information technology." Granić \& Marangunić (2019) clarify that TAM has been the most common model in the past 18 years and has been commonly used in different studies related to the adoption of information technology. Hsu and Chiu (2004) agree that perceived utility in their research is a determining factor for user satisfaction. The indicators used in this analysis, however, were based on Davis (1989), which consists of effective, quality, and ease.

\subsection{System Quality Impacts Customer Satisfaction}

According to Iivari (2005), the consistency of the framework and user satisfaction in individual analyst units was strongly supported. System quality is "the quality of an information system's combination of hardware and software". Previous studies have shown that satisfaction of users is affected significantly by device efficiency (Ho et al., 2019; Iivari, 2005). The provisional allegation in this research was based on the theory, and description presented:

$\mathrm{H}_{1}$ : System quality has a significant influence on the satisfaction of users.

\subsection{The Quality of Information Affects Customer Satisfaction}

The quality of information according to user requirements would increase the degree of user satisfaction. Delone and Mclean's IS performance model (1992) illustrates that the higher the degree of knowledge quality, the greater the satisfaction of the customer. In individual research units, studies have found a clear link between the quality of knowledge and user satisfaction (Almutairi \& Subramanian, 2005; Halawi et al., 2007). A beneficial function of information system performance is the dimension of information quality success. Previous research has shown that the quality of information significantly affects consumer satisfaction ( Jaafreh, 2017; Fitzgerald \& Russo, 2005; Yim \& Shin, 2014 ). Based on the theory and description presented, the provisional allegation in this research was:

$\mathrm{H}_{2}$ : Information quality has a significant influence on the satisfaction of users.

\subsection{Service Quality Influences user satisfaction}

Parasurahman et al. ( 1988) say that consumer satisfaction is improved by a higher degree of service quality. Halawi et al. (2007) found a significant association between service quality and user satisfaction assessed using SERVQUAL. Previous 
research has shown that user satisfaction is greatly impacted by the standard of service (Kuo et al. , 2018; Angelina et al., 2019; Santouridis et al., 2009; Lin et al., 2011). Based on the above theory and definition, in this analysis, the tentative allegation was:

$\mathrm{H}_{3}$ : Service quality has a significant influence on the satisfaction of users.

\subsection{Perceived Usefulness as Moderating Variable}

One of TAM's variables is perceived usefulness. Perceived usefulness is described, according to Davis ( 1989), "as the degree to which an individual believes that the use of certain information systems can enhance efficiency". Based on this concept, it is understood that perceived usefulness is a belief in the process of decision-making. If anyone thinks that it is useful for the scheme, he will use it. If anyone feels that the information system is less sound, on the other hand, they will not use it. Negash et al. (2003) state that "user satisfaction has proven useful in evaluating the effects of IS and internet/web systems and is also a major factor in the intention to use new technology".

In this study, the perceived usefulness was used as a moderating variable to see if the effect of system quality, information quality, and service quality on the satisfaction of users can be strengthened or weakened. The perceived usefulness as a moderating variable was not explored by previous research. The preliminary allegations in this research were based on the theory and explanation:

$\mathrm{H}_{4}$ : The perceived usefulness moderates the impact of system quality on the satisfaction of users.

$\mathrm{H}_{5}$ : The perceived usefulness moderates the impact of information quality on the satisfaction of users.

$\mathrm{H}_{6}$ : The perceived usefulness moderates the impact of service quality on the satisfaction of users.

\subsection{Thinking Framework}

Based on the previous studies, the framework of thinking of this research is displayed in the following Fig 1.

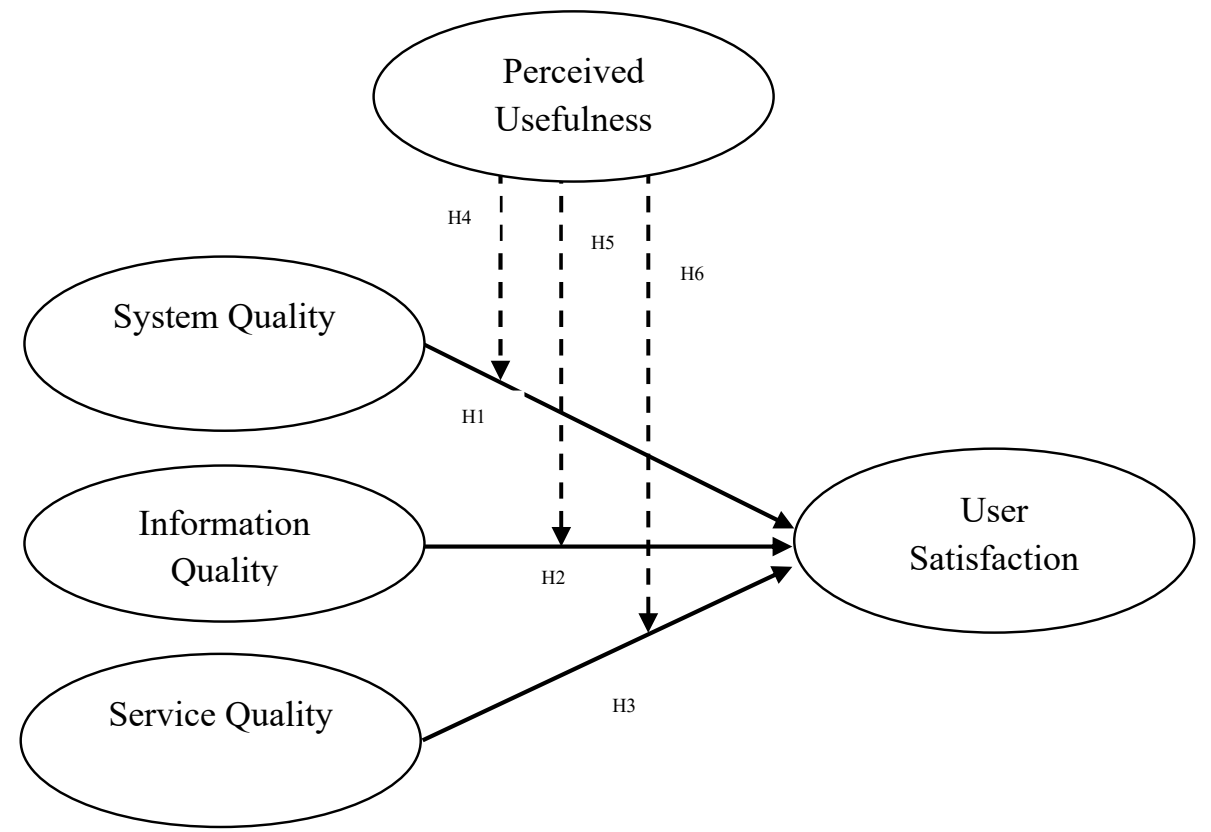

Fig. 1. Thinking Framework

$\begin{array}{ll}\longrightarrow & \text { Influencing Variable } \mathrm{x} \text { and Variable } \mathrm{y} \\ & \text { Moderation }\end{array}$

\section{Research Method}

\subsection{Type of Research}

Since the information was gathered from respondents using a questionnaire, this research was survey research. In this analysis, an online survey was used. 


\subsection{Sampling Technique}

In this analysis, the population was 15,307 regular students in the Bachelor Program (S1) of Bengkulu University. The sampling technique used was the snowball sampling technique. The social media platform involved was WhatsApp, where many students of the University of Bengkulu use it. The questionnaires would begin to spread widely based on the related correlation to the research respondents. The number of samples in this Research was 200 respondents.

\subsection{Validity and Reliability Tests}

\subsubsection{Test of Validity}

This study used convergent validity, with reflective measures evaluated based on factors that measure these constructs (correlation between item scores/component scores and contract scores). Hair et al. (2010) stated that "the value of loading factors greater than \pm 0.30 is considered to meet the minimum level, the value of loading factors \pm 0.40 is considered better and following the rule of thumb used by the researchers, and loading factors $>0.50$ are considered significant". The basic rule of thumb used for the validity of convergence is outer loading $>0.70$, communal loading $>0.50$, and "Average Variance Extracted" (AVE) $>0.50$ (Chin, 1998). The validity test calculations that researchers had done can be seen in the following Table 1.

\section{Table 1}

Summary of validity test result

\begin{tabular}{|c|c|c|c|}
\hline Item & Factor Loading & AVE & Communality \\
\hline "System Quality" & & 0.809 & 0.945 \\
\hline Ease of use & 0.921 & & \\
\hline Flexibility & 0.908 & & \\
\hline System Reliability & 0.893 & & \\
\hline Speed of Acces & 0.911 & & \\
\hline System Security & 0.862 & & \\
\hline "Information Quality" & & 0.651 & 0.871 \\
\hline Availabilty & 0.759 & & \\
\hline Ease of undestanding & 0.898 & & \\
\hline Presentation of Information & 0.885 & & \\
\hline Relevan of need & 0.746 & & \\
\hline Information Accurate & 0.813 & & \\
\hline "Service Quality" & & 0.704 & 0.902 \\
\hline Reponsiveness & 0.769 & & \\
\hline Assurance & 0.835 & & \\
\hline Emphaty & 0.907 & & \\
\hline "User Satisfaction" & & 0.726 & 0.828 \\
\hline Efficiency & 0.889 & & \\
\hline Effectiveness & 0.792 & & \\
\hline Overal Satisfaction & 0.872 & & \\
\hline "Perceived Usefulness" & & 0.701 & 0.794 \\
\hline Effective & 0.836 & & \\
\hline Quality & 0.833 & & \\
\hline Ease & 0.842 & & \\
\hline
\end{tabular}

Based on Table 1, all variables have a communality value of $>0.5$ and AVE $>0.5$. The result has met the criteria of convergent validity so that all indicators are valid and can be used to further analysis.

\subsubsection{Reliability}

In PLS, reliability testing can use two approaches, namely the Cronbach alpha and Composite reliability. The Cronbach alph" or Composite Reliability rule of thumb must be greater than 0.7 , even though 0.6 is appropriate (Hair et al., 2010). Table 2 can be used as the outcome of the reliability review. 
Table 2

Summary table of reliability test result

\begin{tabular}{lll}
\hline Item & Cronbach Alpha & Composite Realibity \\
\hline System Quality & 0,941 & 0.955 \\
Information Quality & 0.888 & 0.902 \\
Service Quality & 0.803 & 0.876 \\
User Satisfaction & 0.811 & 0.888 \\
Perceived Usefulness & 0.788 & 0.875 \\
\hline
\end{tabular}

Table 2 shows that the Cronbach Alpha and the Composite reliability values are above 0.7 for each component. So, it can be concluded that the instruments used are reliable.

\subsection{Method of Analysis}

Analysis of the data used in this research was inferential statistical analysis, namely Structural Equation Model, referred to as SEM. This SEM was operated through the "Partial Least Square" (PLS) software, namely version 3.2.9 of Smart-PLS.

\section{Data Analysis Results}

Data from the test of validity and reliability was then processed to determine the hypothesis testing results through the Structural Equation Model, which was operated through the "Partial Least Square" (PLS) software, namely version 3.2.9 of Smart-PLS. The results of the version 3.2.9 of Smart-PLS can be seen in Fig 2.

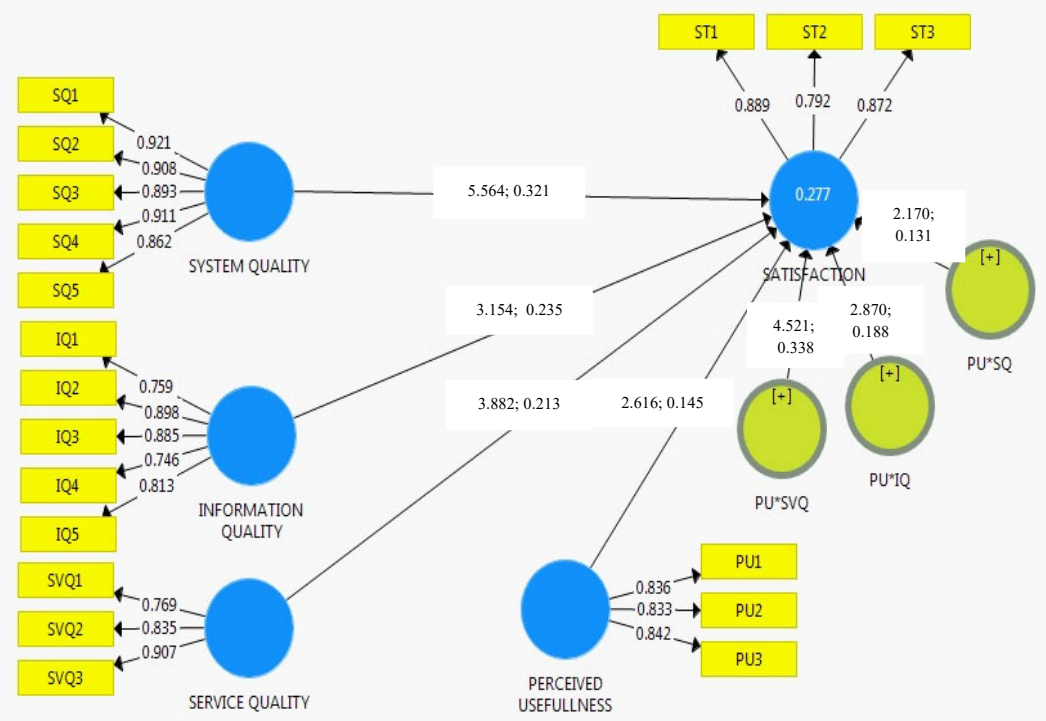

Fig. 2. Structural Model Output

Hypothesis 1: System quality has a positive influence on user satisfaction.

Beta coefficient value of 0.321 and t-value of 5,564 were obtained in the results. The t-value of $>1.64$ (one-sided hypothesis) indicates that "user satisfaction is positively influenced by system quality".

Hypothesis 2: Information quality influences user satisfaction.

Beta coefficient value of 0.235 and t-value of 3.154 were obtained in the results. The t-value of $>1.64$ (one-sided hypothesis) indicates that "user satisfaction is positively influenced by information quality". 
Hypothesis 3: Service quality influences user satisfaction.

Beta coefficient value of 0.213 and t-value of 3.882 were obtained in the results. The t-value of $>1.64$ (one-sided hypothesis) indicates that "user satisfaction is positively influenced by service quality".

Hypothesis 4: Perceived usefulness in moderating The effects quality of system on the satisfaction of users.

The results obtained $t$ value of 2.170 . The $t$ value of $>1.96$ (two-sided hypothesis due to moderation) shows that "the perceived usefulness moderates system quality on user satisfaction".

Hypothesis 5: Perceived usefulness in moderating the effects of the quality of information on user satisfaction.

The results obtained $t$ value of 2.870 . The $t$ value of $>1.96$ (two-sided hypothesis due to moderation) shows that the "PU moderates the effect of the quality of information on user satisfaction".

Hypothesis 6: Perceived usefulness in moderating the effect of the quality of service on user satisfaction.

The results obtained $t$ value of 4.521 . The $t$ value of $>1.96$ (two-sided hypothesis due to moderation) shows that the perceived usefulness moderates service quality's effect on the satisfaction of user.

\section{Discussion}

The aim of this discussion is to test the hypotheses identified as the aims of this analysis.

\subsection{System quality affects positively on user satisfaction}

The result demonstrates that the "system's quality has a positive effect on user satisfaction", which means that better system quality results in increased user satisfaction. This study is in line with some previous research suggesting that the satisfaction of user is influenced by the the quality of system (Tam \& Oliveira, 2016; Kim \& Lee, 2014; Nugroho \& Prasetyo, 2018). The quality of the system is known as the features of information system processing (Delone \& Mclean, 1992)

System consistency is "the degree to which a scheme is easy to use", according to Chin \& Todd (1995). System efficiency is assessed for websites based on reliability and download time. In two separate studies, it is very critical for user satisfaction (Palmer, 2002). According to Kim and Lee (2014), "system quality such as stability, accessibility, response speed, and reliability affect user satisfaction". Students of the University of Bengkulu will achieve satisfaction as users of academic portal information systems to improve their academic performance. The University of Bengkulu must provide a quality system, such as easy to use, response speed, flexibility (easy to accept changes), and system security (protection from the risk of illegal action).

\subsection{The quality of information positively affects user satisfaction}

The finding indicates that the quality of information has a positive impact on user satisfaction means that improved the quality of information results in increased the satisfaction of user. This study is in line with previous research, suggesting that the satisfaction of user is affected by the quality of information (Chen \& Cheng, 2009; Rai et al., 2002). A website must contain specific, useful, current, and accurate details, according to Lim \& Ting (2012). Irrelevant, incomplete, or obsolete information may affect user satisfaction. Research by Delone \& Mclean (1992) indicates that information quality is a system that can affect user satisfaction. Thus, the University of Bengkulu must provide quality information on the academic portal information system to be satisfied and improve their academic 
performance. The quality information must contain complete information, ease of understanding, information display format, relevance, and data).

\subsection{Service quality affects positively on user satisfaction}

The findings showing that service quality positively affects user satisfaction mean that improved service quality contributes to an improvement in user satisfaction. This study is in line with previous studies that show that the standard of service has a significant influence on customer satisfaction (Lin, 2007; Qin \& Prybutok, 2009; Kim et al., 2005; Almarashdeh, 2016). Researchers have recognized the value of service quality as a measure of information system success since the 1990s (April \& Pather, 2008). Pitt et al. (1995) evaluate the instrument from an IS perspective and suggest that constructs of service quality can be added to the model of D\&M. According to Jiang (2002), "Service quality is an important factor of user satisfaction." Service quality refers to how good information service providers provide the service. As users of information systems, university students will achieve satisfaction if the University of Bengkulu offers quality services. Employees have to provide users with fast service. Employees have enough expertise to perform their work adequately. Employees need to understand users' specific needs.

\subsection{Perceived usefulness in moderating the effect the quality of a system, the quality of information, and the quality of service partially on user satisfaction.}

The outcome of this analysis was:

1. The perceived usefulness reinforces the influence of the quality of system on user satisfaction. It means that the "perceived usefulness" (effective, quality, and ease) will enhance the satisfaction of user.

2. The "perceived usefulness" moderates (strengthens) the impact of the quality of information on user satisfaction. It implies that the perceived utility (effective, quality, and ease) will support the efficiency of satisfaction details.

3. The perceived usefulness moderates (strengthens) the impact on user satisfaction of the service quality. It implies that the usefulness perceived (effective, quality, and ease) will improve user satisfaction.

These three research results are not supported by similar findings from previous research since this topic has not yet been studied in any research. The perceived usefulness is "the perception in which people believe that certain subjects' use will improve their work performance" (Davis, 1989). The University of Bengkulu must provide an academic portal that is useful for students (users), such as an academic portal that can improve student lectures' effectiveness, improve lectures' quality, and facilitate lectures.

\section{Conclusion}

This research obtained: (1) The quality of the system affects user satisfaction with the academic portal information system. To improve student performance, the University of Bengkulu must provide a quality system, such as easy to use, response speed, flexibility (easy to accept changes) and system security (protection from the risk of illegal action); (2) The quality of information on the academic portal influences the satisfaction of user. To improve student performance, the University of Bengkulu must provide quality information. The quality information must contain the availability of complete information, ease of understanding, information display format, relevance, and accuracy of information availability of completeness, ease of understanding (ease of understanding), presentation of information (format), the relevance of needs (relevance), and accuracy of information (accurate); (3) Service quality determines customer satisfaction. If the University of Bengkulu provides quality services such as staff 
providing fast service to users, staff have adequate knowledge to conduct their jobs properly; staff need to understand the particular needs of users, university students as users of the information system can achieve satisfaction; and (4) Perceived usefulness moderates the relationship between the quality of system, the quality of information, and the quality of service partially on user satisfaction. Bengkulu University must provide an academic portal that is useful for students (users) to improve their performance. This research also contributes to providing guidelines and recommendations to other researchers in the future.

\section{Acknowledgements}

This research was supported by Lembaga Penelitian dan Pengabdian (LPPM) Universitas Bengkulu. [No:2068/UN30.15/PG/2020]

\section{References}

Almarashdeh, I. (2016). Sharing instructors experience of learning management system: A technology perspective of user satisfaction in distance learning course. Computers in Human Behavior, 63, 249 255. https://doi.org/10.1016/j.chb.2016.05.013

Almutairi, H., \& Subramanian, G. H. (2005). An empirical application of the DeLone and Mclean model in the Kuwaiti private sector. Journal of Computer Information Systems, 45(3), 113-122. https://doi.org/10.1080/08874417.2005.11645849

Amoli, E. . J., \& Farhoomand, A. F. (1996). A structural model of end user computing satisfaction and user performance. Information and Management, 30, 65-73. https://doi.org/10.1016/03787206(95)00052-6

Angelina, R. J., Hermawan, A., \& Suroso, A. I. (2019). Analyzing E-Commerce Success using DeLone and McLean Model. Journal of Information Systems Engineering and Business Intelligence, 5(2), 156-162. https://doi.org/10.20473/jisebi.5.2.156-162

April, G. D., \& Pather, S. (2008). Evaluating Service Quality Dimensions within e-Commerce SMEs. Electronic Journal Information Systems Evaluation, 11(3), 109-124.

Bokhari, R. H. (2005). The relationship between system usage and user satisfaction: A meta-analysis. Journal of Enterprise Information Management, 18(2), 211-234. https://doi.org/10.1108/17410390510579927

Chen, C. W. D., \& Cheng, C. Y. J. (2009). Understanding consumer intention in online shopping: A respecification and validation of the DeLone and McLean model. Behaviour and Information Technology, 00(0), 1-11. https://doi.org/10.1080/01449290701850111

Chin, W. W. (1998). The partial least squares approach to structural equation modelling. Modern Methods for Business Research, 295(2), 295-336.

Chin, W. W., \& Todd, P. A. (1995). On the use, usefulness, and ease of use of structural equation modeling in mis research: A note of caution. MIS Quarterly: Management Information Systems, 19(2), 237-246. https://doi.org/10.2307/249690

Chiu, C. M., Chiu, C. S., \& Chang, H. C. (2007). Examining the integrated influence of fairness and quality on learners' satisfaction and Web-based learning continuance intention. Information Systems Journal, 17, 271-287. https://doi.org/10.1111/j.1365-2575.2007.00238.x

Davis, F. D. (1989). Information Technology Introduction. MIS Quarterly, 13(3), 319-340.

Delone, W., \& Mclean, E. (1992). Information Systems Success: The Quest for the Dependent Variable. https://doi.org/10.1287/isre.3.1.60

Delone, W., \& Mclean, E. (2003). The DeLone and McLean Model of Information Systems Success : A Ten-Year Update. Journal of Management Information Systems, 19(4). https://doi.org/10.1080/07421222.2003.11045748

Dessler, G. (2017). Human Resource Management Fifteenth Edition.

Fitzgerald, G., \& Russo, N. L. (2005). The turnaround of the London Ambulance Service ComputerAided Despatch system (LASCAD). European Journal of Information Systems, 14(3), 244-257. 
https://doi.org/10.1057/palgrave.ejis.3000541

Gable, G. G., Sedera, D., \& Chan, T. (2008). Re-conceptualizing Information System Success : The ISImpact Measurement Model Re-conceptualizing Informa. Journal of the Association for Information Systems, 9(7), 377-408.

Granić, A., \& Marangunić, N. (2019). Technology acceptance model in educational context: A systematic literature review. British Journal of Educational Technology, 50(5), 2572-2593. https://doi.org/10.1111/bjet.12864

Hair, J. R., Black, W. C., Babin, B. J., \& Anderson, R. E. (2010). Multivariate Data Analysis (Seven Edit). Pearson Prentice Hall.

Halawi, L. A., McCarthy, R. V., \& Aronson, J. E. (2007). An empirical investigation of knowledge management systems' success. Journal of Computer Information Systems, 48(2), 121-135. https://doi.org/10.1080/08874417.2008.11646014

Ho, K. F., Ho, C. H., \& Chung, M. H. (2019). Theoretical integration of user satisfaction and technology acceptance of the nursing process information system. PLoS ONE, 14(6), 1-14. https://doi.org/10.1371/journal.pone.0217622

Hsu, M. H., \& Chiu, C. M. (2004). Predicting electronic service continuance with a decomposed theory of planned behaviour. Behaviour and Information Technology, 23(5), 359-373. https://doi.org/10.1080/01449290410001669969

Iivari, J. (2005). An Empirical Test of the DeLone-McLean Model of Information System Success. Data Base for Advances in Information Systems, 36(2), 8-27. https://doi.org/10.1145/1066149.1066152

Jaafreh, A. B. (2017). Evaluation Information System Success: Applied DeLone and McLean Information System Success Model in Context Banking System in KSA. International Review of Management and Business Research, 6(2), 829-845.

Jiang, J. J., Klein, G., \& Carr, C. L. (2002). Measuring information system service quality: SERVQUAL from the other side. MIS quarterly, 26(2), 145-166.

Kim, Y., Eom, M., \& Ahn, J. (2005). Measuring is service quality in the context of the service qualityuser satisfaction relationship. Journal of information technology theory and application, 7(2), 5370.

Kim, Y., \& Lee, H. S. (2014). Quality, perceived usefulness, user satisfaction, and intention to use: An empirical study of ubiquitous personal robot service. Asian Social Science, 10(11), 1-16. https://doi.org/10.5539/ass.v10n11p1

Kotler, P., \& Keller, K. (2015). marketing management. In Small Business Marketing. https://doi.org/10.1007/978-1-137-32601-0 12

Kuo, K. M., Liu, C. F., Talley, P. C., \& Pan, S. Y. (2018). Strategic improvement for quality and satisfaction of hospital information systems. Journal of Healthcare Engineering. https://doi.org/10.1155/2018/3689618

Laudon, K. C., \& Laudon, J. P. (2014). Management Information Systems . Managing the Digital Firm.

Lim, W. M., \& Ting, D. H. (2012). E-shopping: An analysis of the uses and gratifications theory. Modern Applied Science, 6(5), 48-63. https://doi.org/10.5539/mas.v6n5p48

Lin, C. C., Wu, H. Y., \& Chang, Y. F. (2011). The critical factors impact on online customer satisfaction. Procedia Computer Science, 3, 276-281. https://doi.org/10.1016/j.procs.2010.12.047

Lin, H. F. (2007). The impact of website quality dimensions on customer satisfaction in the B2C Ecommerce context. Total Quality Management, 18(4), 363-378. https://doi.org/10.1080/14783360701231302

Michel, S., \& Cocula, F. (2017). Impact of the Three IS Qualities On User Satisfaction in an Information-Intensive Sector. Electronic Journal of Information Systems Evaluation, 20(2), 85-101.

Negash, S., Ryan, T., \& Igbaria, M. (2003). Quality and effectiveness in Web-based customer support systems. Information and Management, 40, 757-768. https://doi.org/10.1016/S03787206(02)00101-5

Nugroho, Y., \& Prasetyo, A. (2018). Assessing information systems success: A respecification of the DeLone and McLean model to integrating the perceived quality. Problems and Perspectives in 
Management, 16(1), 348-360. https://doi.org/10.21511/ppm.16(1).2018.34

O’Brien, J. A., \& Marakas, G. (2011). Management Information Systems.

Palmer, J. (2002). Web Site Usability,Design, and Performance Metric. Information Systems Research, 13(2), 151-167. https://doi.org/10.1111/j.1468-4004.2006.47617.x

Parasurahman, A., Zeithaml, V., \& Berry, L. L. (1988). SERQUAL: A Multiple-Item Scale for Measuring Consumer Perception of Service Quality. Journal of Retailling, 64(1), 12-40. https://doi.org/10.1002/9781118785317.weom090654

Petter, S., DeLone, W., \& McLean, E. (2008). Measuring information systems success: Models, dimensions, measures, and interrelationships. European Journal of Information Systems, 17, 236263. https://doi.org/10.1057/ejis.2008.15

Petter, S., Delone, W., \& McLean, E. R. (2013). Information systems success: The quest for the independent variables. Journal of Management Information Systems, 29(4), 7-62. https://doi.org/10.2753/MIS0742-1222290401

Pitt, L. F., Watson, R. T., \& Kavan, C. B. (1995). Service quality: A measure of information systems effectiveness. MIS Quarterly, 19(2), 173-185. https://doi.org/10.2307/249687

Qin, H., \& Prybutok, V. R. (2009). Service quality, customer satisfaction, and behavioral intentions in fast-food restaurants. International Journal of Quality and Service Sciences, 1(1), 78-95. https://doi.org/10.1108/17566690910945886

Rai, A., Lang, S. S., \& Welker, R. B. (2002). Assessing the validity of IS success models: An empirical test and theoretical analysis. Information Systems Research, 13(1), 50-69. https://doi.org/10.1287/isre.13.1.50.96

Santouridis, I., Trivellas, P., \& Reklitis, P. (2009). Internet service quality and customer satisfaction: Examining internet banking in Greece. Total Quality Management and Business Excellence, 20(2), 223-239. https://doi.org/10.1080/14783360802623084

Seddon, P. B., \& Min-Yen Kiew. (2020). A partial test and development of delone and mclean's model of is success3. Australasian Journal of Information Systems, 4(1), 90-109. https://doi.org/10.3127/AJIS.V24I0.2769

Tajuddin, M. (2015). Modification of Delon and McLean model in the success of information system for good university governance. Turkish Online Journal of Educational Technology, 14(4), 113123.

Tam, C., \& Oliveira, T. (2016). Understanding the impact of m-banking on individual performance: DeLone \& McLean and TTF perspective. Computers in Human Behavior, 61, 233-244. https://doi.org/10.1016/j.chb.2016.03.016

Van Vuuren, D. P., Riahi, K., Moss, R., Edmonds, J., Thomson, A., Nakicenovic, N., Kram, T., Berkhout, F., Swart, R., Janetos, A., Rose, S. K., \& Arnell, N. (2011). A proposal for a new scenario framework to support research and assessment in different climate research communities. Global Environmental Change, 22(1), 21-35. https://doi.org/10.1016/j.gloenvcha.2011.08.002

Yakubu, M., \& Dasuki, S. . (2018). Asessing E L Earning S Ystems S Uccess in N Igeria : an Aplication of the DeLone and McLean I nformation Systems Success M Odel. Journal of Information Thecnology Education: Research, 17, 182-202.

Yim, S., \& Shin, M. (2014). Effects of System Quality and Information Quality on the Use and Job Performance of an Enterprise Mobility Solution for a Mobile Office with a Consideration of Task Mobility and Task Interdependence as Control Variables. Asia Pacific Journal of Information Systems, 24(2), 115-140. https://doi.org/10.14329/apjis.2014.24.2.115 
(C) 2021 by the authors; licensee Growing Science, Canada. This is an open access article distributed under the terms and conditions of the Creative Commons Attribution (CC-BY) license (http://creativecommons.org/licenses/by/4.0/). 